\title{
Pathogen Challenge, Salicylic Acid, and Jasmonic Acid Regulate Expression of Chitinase Gene Homologs in Pine
}

\author{
John M. Davis, ${ }^{1}$ Haiguo Wu, ${ }^{1}$ Janice E. K. Cooke, ${ }^{1}$ Jon M. Reed, ${ }^{1}$ K. Scott Luce, ${ }^{1}$ \\ and Charles H. Michler ${ }^{2}$ \\ ${ }^{1}$ School of Forest Resources and Conservation, and Plant Molecular and Cellular Biology Program, University of Florida, \\ Gainesville, FL 32611 U.S.A.; ${ }^{2}$ USDA Forest Service, North Central Research Station, Hardwood Tree Improvement and \\ Regeneration Center, Purdue University, West Lafayette, IN 47907 U.S.A.
}

Submitted 18 September 2001. Accepted 14 December 2001.

To better understand the molecular regulation of defense responses in members of the genus Pinus, we tested the expression of various chitinase homologs in response to pathogen-associated signals. PSCHI4, a putative extracellular class II chitinase, was secreted into liquid medium by pine cells and was also secreted by transgenic tobacco cells that ectopically expressed pschi4. Extracellular proteins of pine were separated by isoelectric focusing; PSCHI4 was not associated with fractions containing detectable $\beta-N$ acetylglucosaminidase or lysozyme activities. However, other fractions contained enzyme activities that increased markedly after elicitor treatment. The pschi4 transcript and protein accumulated in pine seedlings challenged with the necrotrophic pathogen Fusarium subglutinans f. sp. pini, with the protein reaching detectable levels in susceptible seedlings concomitant with the onset of visible disease symptoms. Additional chitinase transcripts, assigned to classes I and IV based on primary sequence analysis, were also induced by pathogen challenge. Jasmonic acid induced class I and class IV but not class II chitinase, whereas salicylic acid induced all three classes of chitinase. These results show that multiple chitinase homologs are induced after challenge by a necrotrophic pathogen and by potential signaling molecules identified in angiosperms. This suggests the potential importance of de novo pathogenesisrelated (PR) gene expression in pathogen defense responses of pine trees.

Additional keywords: disease resistance, Pinus elliottii, Pinus taeda, pitch canker.

There are more than 100 different species within the genus Pinus, and these species are panglobally distributed (Richardson and Rundel 1998). Pines account for the majority of the annual harvest of forest trees in the United States, with the annual harvest valued at approximately $\$ 19$ billion (McKeever and

Corresponding author: John M. Davis; E-mail: jmdavis@ufl.edu

Current address of H. Wu: GeneData Inc., 1601 Trapelo Road, Suite 194, Waltham, MA 02451 U.S.A.

Current address of J. E. K. Cooke: Canadian Forest Service, Laurentian Forestry Centre, 1055 Rue du PEPS, Sainte-Foy, QC G1V 4C7 Canada.

Current address of K. S. Luce: Department of Biochemistry, Vanderbilt University School of Medicine, Nashville, TN 37232 U.S.A.
Howard 1996). The economic value of pines is significantly reduced or imperiled by diseases. Pitch canker disease is an episodic, economically important disease of pines (Dwinell and Phelps 1977; Dwinell et al. 1977) that is incited by the wound pathogen Fusarium subglutinans (Wollenweb. \& Reinking) P.E. Nelson, T.A. Toussoun, \& Marasas f. sp. pini. Symptoms of pitch canker include discoloration and copious resin ("pitch") exudation from the stem. Resistance to pitch canker differs widely among pine species (Hodge and Dvorak 2000). In the southern pine species Pinus elliottii Engelm. var. elliottii (slash pine), families that differ in their genetic resistance to pitch canker have been identified (Blakeslee and Rockwood 1978; Rockwood et al. 1988). We are using families that vary in their resistance to pitch canker disease in order to understand defense mechanisms in pines.

The obvious and highly effective defense strategy of exuding resin from wound sites is thought to function as a cleansing mechanism to prevent disease and discourage herbivory (Phillips and Croteau 1999). Despite the general effectiveness of this defense mechanism, certain pathogenic fungi such as $F$. subglutinans can tolerate resin and even stimulate its production. Thus, resistant pines must employ other mechanisms of defense in addition to resin production. Comparatively little is known about these other mechanisms and about how they compare/contrast to well-characterized defense mechanisms in angiosperms.

The de novo synthesis of pathogenesis-related (PR) proteins is part of a diverse set of plant responses to pathogen challenge (Dixon and Harrison 1990; Dixon and Lamb 1990; Enyedi et al. 1992; Yang et al. 1997). Chitinases are PR proteins that hydrolyze chitin, a $\beta$-linked polymer of $N$-acetylglucosamine and a constituent of the cell wall of many fungi. In addition to being useful markers for host defense responses, chitinases may condition disease resistance based on antimicrobial activity in vitro and in planta (Benhamou et al. 1990; Mauch et al. 1988) and when ectopically expressed in transgenic plants (Broglie et al. 1991; Grison et al. 1996; Jach et al. 1995). Chitinases are diverse enzymes that evolve rapidly (Bishop et al. 2000) and are classified into classes I, II, III, and IV based on their structural features, enzymatic properties, and subcellular compartmentation. Class I (vacuolar), II, and IV (extracellular) enzymes are structurally related, whereas class III enzymes are usually considered lysozymes with chitinase activity (Collinge et al. 1993; Graham and Sticklen 1994). Individual plant species can contain many different chitinases that are distinct in terms of their regulation and function. 
Coordinated expression of PR gene regulons is thought to be mediated, in part, by the accumulation of the small diffusible signaling molecules salicylic acid (SA) and jasmonic acid (JA) (Enyedi et al. 1992; Schenk et al. 2000; Yang et al. 1997). Exogenous applications of these molecules can mimic the endogenous increases that occur after pathogen challenge. A combination of pharmacological studies and genetic analysis suggests that different pathogens elicit distinct host responses, with a tendency for necrotrophic pathogens to elicit JA-dependent responses and biotrophic pathogens to elicit SA-dependent responses (McDowell and Dangl 2000; Thomma et al. 2001).

To test the potential involvement of PR proteins, SA, and JA in the response of pines to pathogen challenge, we examined the regulation of a class II chitinase homolog, pschi4, that had previously exhibited elicitor-stimulated transcript accumulation (Mason and Davis 1997; Wu et al. 1997). While assessing the in planta role of pschi4, we identified several other chitinase cDNAs that were coregulated with pschi4, suggesting that de novo chitinase expression is a conserved feature of pathogen responses among gymnosperms and angiosperms. Taken together, our results suggest that PR proteins may play important roles in the responses of pines to certain pathogens.

\section{RESULTS}

\section{Verification of pschi4 intron splicing and antibody production.}

At the time this work began, we had not obtained a fulllength pschi4 cDNA. Our first objective was to clone the cDNA for production of recombinant protein in Escherichia coli and subsequent antibody production. We chose not to clone the cDNA from pine tissues because of the presence of several pschi4-related genes revealed by Southern analysis (Wu et al. 1997). Instead, we cloned the pschi4 cDNA from transgenic tobacco that contained a pschi4 gene under the control of

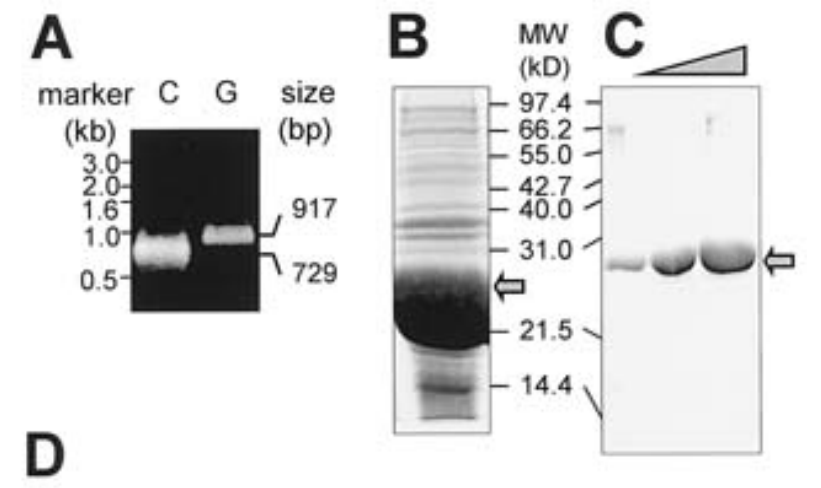

\section{MASMTGGQQMGRDPNSSDVPSAQQGV} vector

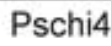

Fig. 1. Recombinant PSCHI4 expression in Escherichia coli. A, Primers directed against the $5^{\prime}$ and $3^{\prime}$ ends of the pschi4 coding region were used to amplify pschi4 with introns removed, using as a template the firststrand cDNA (lane C) from transgenic tobacco expressing pschi4 under the control of its own promoter, or with introns intact, using as a template a genomic subclone of pschi4 (lane G). Recombinant protein was B, expressed in E. coli and the crude extract was subjected to sodium dodecyl sulfate-polyacrylamide gel electrophoresis (arrow indicates recombinant PSCHI4); C, gel-purified and tested for purity (lanes are 1, 4, and $8 \mu \mathrm{l}$, respectively, of gel-purified protein); and $\mathbf{D}$, subjected to N-terminal sequencing to confirm its identity as PSCHI4. "Vector" indicates amino acid residues present in recombinant PSCHI4 but derived from the expression vector. its own regulatory sequences (Wu et al. 1997) and then used the RNA as a template for reverse-transcription-polymerase chain reaction (RT-PCR). This experiment also confirmed the correct splicing of two introns by comparing the size (Fig. 1A) and sequence of the pschi4 gene with its cDNA. PSCHI4 expressed in E. coli showed the expected molecular weight and $\mathrm{N}$-terminal sequence for this recombinant protein (Fig. 1B to D). Recombinant PSCHI4 (r-PSCHI4) was used to elicit antibodies.

\section{PSCHI4 is secreted by tobacco cells.}

Chitinases can be extracellular or vacuolar. We predicted that PSCHI4 was extracellular based on its relatedness to class II chitinase (Wu et al. 1997). However, cryptic vacuolar sorting determinants can occur in various regions of PR proteins (Neuhaus and Rogers 1998). Therefore, we tested the targeting of PSCHI4 in a heterologous system. Suspension cultures, initiated from leaves of transgenic tobacco lines containing pschi4 under the control of its own promoter, accumulated pschi4 transcripts (Fig. 2A). Antibodies against PSCHI4 recognized a protein in the culture medium of cells transformed with pschi4 (i.e., extracellular) but not in whole-cell extracts (i.e., vacuolar). Chitosan treatment did not stimulate an appreciable accumulation of PSCHI4. Immunoreactive proteins were not detected in whole-cell extracts derived from vector-transformed tobacco cells or on blots probed with preimmune serum (Fig. 2B). These results support the prediction that PSCHI4 is extracellular.

\section{PSCHI4 is secreted by slash and loblolly pine cells.}

To investigate the localization of PSCHI4 in pine, suspension cell cultures of slash pine and loblolly pine ( $P$. taeda L.) were separated into cells and culture medium. Immunoreactive proteins were identified in the medium of both slash and loblolly pine cultures (Fig. 3). In addition to putative PSCHI4, one or more immunoreactive proteins approximately $32 \mathrm{kDa}$ in size

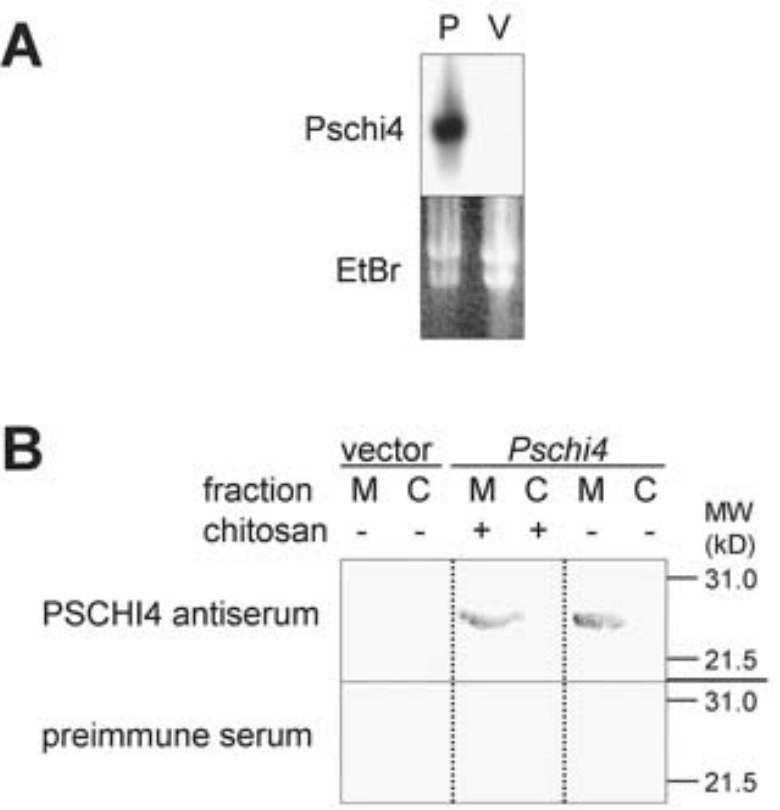

Fig. 2. PSCHI4 is secreted in a heterologous system. A, Autoradiograph (top panel) and ethidium bromide-stained gel (bottom panel) of a northern blot with total RNA ( $5 \mu \mathrm{g}$ per lane) from transgenic tobacco cell cultures containing pschi4 (lane P) or pBI101 vector (lane V) that was probed with pschi4. B, Western blot of protein from medium (lanes M) and whole-cell extracts (lanes C) treated with chitosan $(+)$ or untreated $(-)$ and probed with anti-PSCHI4 (top panel) or preimmune serum (lower panel). Equal loading of protein samples was confirmed by Coomassie staining of an equivalent gel (data not shown). 
were detected in loblolly pine whole-cell extracts. This is most likely due to the cross-reactivity of the antibody to related proteins, potentially chitinase homologs that are targeted to the vacuole.

\section{Major fractions of hydrolytic enzyme activity do not contain PSCHI4.}

To determine if antimicrobial activities could be attributed to PSCHI4 accumulation in response to an elicitor, we used preparative isoelectric focusing to fractionate the medium of pine suspension cultures. The highest level of $\beta-N$-acetylglucosaminidase (referred to here as "chitinase") activity was observed in a broad peak at $\mathrm{pH} 7$ and increased about twofold in response to chitosan treatment (Fig. 4A). This confirmed our previous measurement of a chitosan-stimulated, twofold increase in extracellular chitinase, with chitin as a substrate (Popp et al. 1997). Lysozyme activity was observed in a peak at pH 3 and also increased about twofold in response to chitosan treatment (data not shown).

PSCHI4 exhibited an isoelectric point of approximately 5, which was consistent with the prediction of 5.8 based on primary sequence (Expert Protein Analysis SYstem server, Swiss Institute of Bioinformatics). PSCHI4 focused between peaks of chitinase activity ( $\mathrm{pH} 7)$ and lysozyme activity $(\mathrm{pH} 3)$ and was, therefore, not the source of the main fractionated chitinase and lysozyme activities. The overall quantity of PSCHI4 did appear to increase in response to chitosan induction (Fig. 4B), implying a potential role in defense. The existence of more than one isoform of PSCHI4 is most apparent in the uninduced cultures, in which peaks of PSCHI4 are higher in fractions 8 and 10 than in fraction 9 (Fig. 4B, lower); this was reproducible in different Rotofor separations (Bio-Rad, Hercules, CA, U.S.A.).

\section{pschi4 is differentially regulated}

\section{in resistant and susceptible genotypes.}

To evaluate the regulation of pschi4 mRNA and protein, we utilized open-pollinated slash pine seedlots designated as resistant (R) and susceptible (S) to pitch canker disease and challenged them with $F$. subglutinans f. sp. pini. Resistant seed-

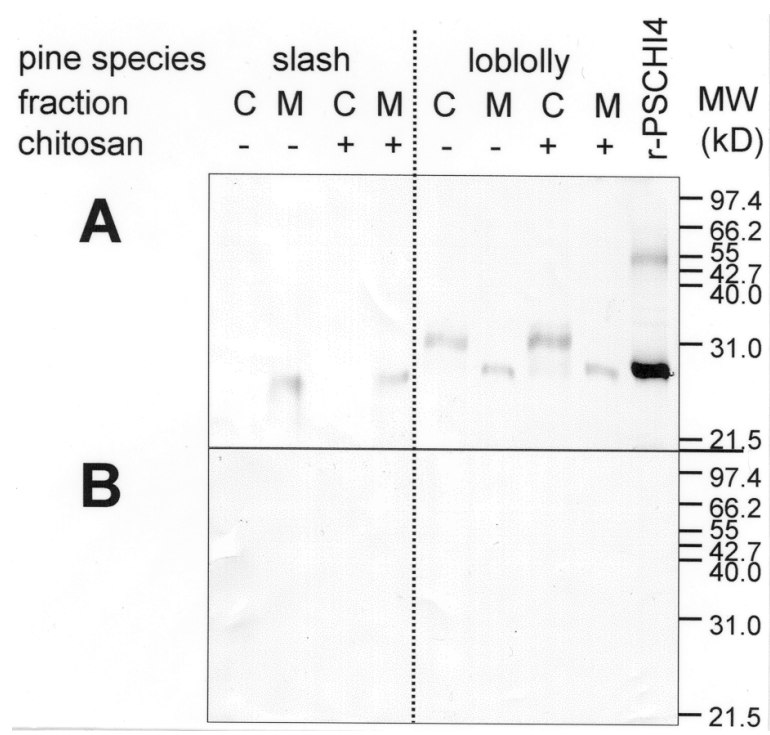

Fig. 3. PSCHI4 is secreted by slash and loblolly pine cell cultures. Western blot of protein from medium (lanes M) and whole-cell extracts (lanes C) treated with chitosan (+) or untreated (-) and A, probed with antiPSCHI4 or B, probed with preimmune serum. Crude recombinant PSCHI4 (r-PSCHI4) was loaded as a positive control for antibody recognition. Equal loading of protein samples was confirmed by Coomassie staining of an equivalent gel (data not shown). lings accumulated pschi4 transcript at low levels 3 and 7 days after challenge, but no transcript was detected 14 days after challenge (Fig. 5A). No disease symptoms were detected in resistant seedlings 14 days after challenge. Susceptible seedlings lacked detectable pschi4 transcript at 0 and 3 days after challenge, but they accumulated high levels of transcript 7 and 14 days after challenge. Susceptible seedlings showed typical symptoms of pitch canker disease 14 days after challenge, including purple tissue discoloration and discharge of resin from wound inoculation sites. PSCHI4 protein was detectable by western analysis, only in tissues with visible disease symptoms, i.e., in susceptible seedlings 14 days after challenge (Fig. $5 \mathrm{~B}$ and $\mathrm{C}$ ). No signal was detected in blots incubated with preimmune serum (data not shown).

\section{Multiple chitinase genes are responsive to pathogen, JA, and SA.}

The enzymatic activities exhibited by the cell cultures suggest that chitinase homologs other than PSCHI4 are probably involved in pine defense responses. To identify other potential PR genes, we performed a differential display of mRNA on pathogen- and elicitor-challenged seedlings, which allowed us to identify other chitinase homologs (Table 1). Two cDNA clones (Pechil and Pechi191) were assigned to class I based on the presence of a putative C-terminal vacuolar sorting determinant in Pechi191 (LIKTVV) (Neuhaus and Rogers 1998). Four other cDNA clones (Pechi73, Pechi80, Pechi155, and Pechi270) appeared to be derived from the same mRNA and were assigned to class IV based on $93 \%$ nucleotide sequence identity to class IV chitinase cDNAs from white spruce (Dong and Dunstan 1997) and several angiosperms. The three classes of chitinase cDNAs did not hybridize to one another on DNA slot blots under standard hybridization and washing conditions (data not shown).

To identify signals that could induce the expression of the chitinase homologs, we assayed their regulation by pathogen challenge and by the small signaling molecules SA and JA. Transcripts of all three chitinase homologs accumulated in pathogen-challenged tissues (Fig. 6), defining them functionally as PR genes. To gain insight into the potential endogenous regulatory pathways that are capable of inducing the chitinase homologs during a defense response, we applied solutions of JA and SA as foliar sprays and root drenches to pine seedlings. All three chitinase homologs were induced by SA, but only class I and IV chitinases were induced by JA (Fig. 6). Pathogen challenge was a more effective inducer than either JA or SA treatment (Fig. 6, note that the Path lanes are loaded with less RNA than the other samples).

\section{DISCUSSION}

Previous work in our laboratory identified an apparent class II chitinase homolog, pschi4, that was induced at the mRNA level by the general elicitor chitosan and by mechanical injury (Mason and Davis 1997; Wu et al. 1997, 1999). In the studies reported in this paper, we extend those findings and show that PSCHI4 is indeed extracellular, as expected for a class II enzyme, and is induced by pathogen challenge at both mRNA and protein levels. Furthermore, we have identified other chitinase gene homologs that are induced by the necrotrophic pathogen $F$. subglutinans $\mathrm{f}$. sp. pini, revealing programs of PR gene expression in pines that are potentially downstream of the small signaling molecules SA and JA.

\section{Chitinases and disease resistance.}

Chitinases belong to a diverse family of hydrolytic enzymes, some of which can condition disease resistance when ectopi- 
cally overexpressed in transgenic plants (Broglie et al. 1991; Grison et al. 1996). The pathogen-responsive expression of pschi4 in pine seedlings and its apparent accumulation in elicitortreated cell cultures is suggestive of a role in a resistance response. However, the level of PSCHI4 enzyme activity was low compared with that of other extracellular chitinases (Fig. 4). This implies that extracellular enzymes other than PSCHI4 are poised to play a more direct role in defense than is PSCHI4. In fact, class II chitinase usually exhibits a lower level of activity than class I or class IV chitinase because of the absence (in class II) of a lectinlike chitin-binding domain near the amino terminus of the mature protein (Collinge et al. 1993; Graham and Sticklen 1994). Furthermore, PSCHI4 protein accumulation was detected only in susceptible seedlings that exhibited visible disease symptoms (Fig. 5), presumably because a large proportion of the host cells are in contact with the necrotrophic pathogen at this late stage of the interaction. A similar result in which a defense-associated process (soluble chitinase activity) was induced after, or concomitant with, the onset of visible disease symptoms was observed in Pythium-challenged conifer seedlings (Kozlowski and Metraux 1998). The low level of activity and late induction of PSCHI4 suggest that it plays no role in conditioning resistance to pitch canker disease. It is relevant to note that previous reports on the inducibility of pschi4 transcripts were suggestive of a defensive role (Wu et al. 1999); however, our more in-depth analysis at the protein and activity levels have helped place those previous data into context. Definitive experiments with transgenic pines will be required to assess the potential roles of PSCHI4 and other chitinase homologs in pathogen defense.

Given the above observations, the biochemical function of PSCHI4 is not clear. It has been suggested that class II chitinases may act as low-level "surveillance" enzymes that elevate or amplify signal intensity by releasing small quantities of elicitors from pathogen cell walls after infection (Mauch and Staehelin 1989). This model raises the possibility that the expression of PSCHI4 protein in disease-resistant seedlings was low or localized to a few cells, such that the expression was below our detection limit (Fig. 5B). The detection of a low level of pschi4 transcript in resistant tissues (Fig. 5A) is consistent with this idea. An alternative model is based on the observation that certain extracellular chitinases in spruce roots can modify fungal elicitors released from the cell wall of mycorrhizal fungi, such that host defense responses are not induced (Salzer et al. 1997a, 1997b). It is unlikely that PSCHI4 plays this role, however, because the relevant spruce enzymes hydrolyzed chitin to its constituent monomers (Salzer et al. 1997a), an activity not detected for PSCHI4 (Fig. 4). The elicitor-inducible peak of chitinase activity at pI 7 probably contains pine enzymes that are orthologous to the elicitor-modifying enzymes from spruce because of the presence of appropriate enzyme activity and pI (Fig. 4). Another possibility is that PSCHI4 plays a role in processes other than defense.

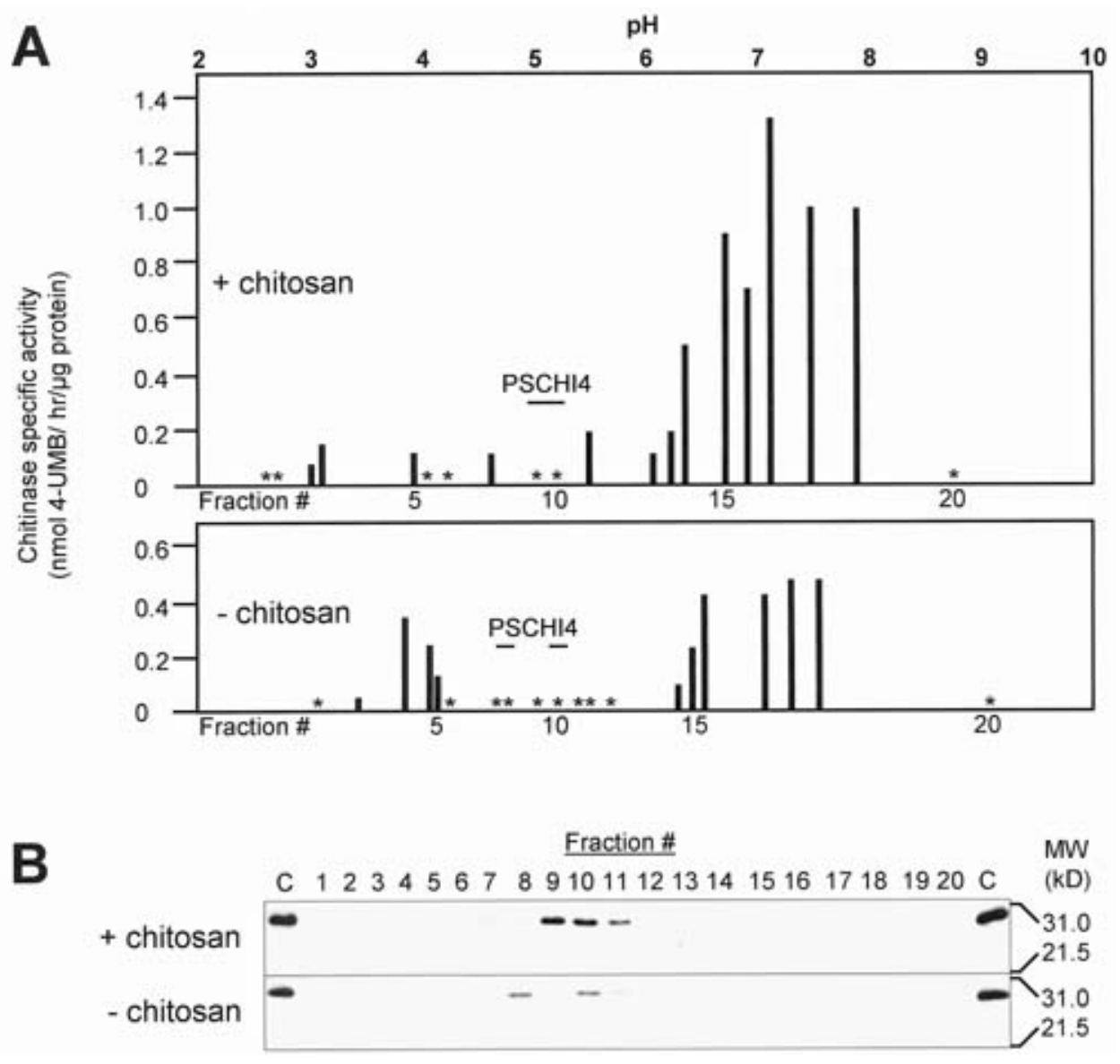

Fig. 4. Neither constitutive nor elicitor-inducible $\beta$ - $N$-acetylglucosaminidase (referred to as "chitinase") activity is associated with PSCHI4. A, Enzymespecific activity was tested in fractionated medium from chitosan-induced (top panel) and untreated (bottom panel) slash pine cell cultures. The pH and the number of each fraction are designated on the top and bottom $x$ axis, respectively. The specific activity of each fraction represents an average of two reactions performed in parallel; duplicate reactions differed less than 10\%. Results from single, typical Rotofor separations are presented. Asterisks are drawn over fractions that lacked detectable activity. Horizontal bars are drawn over the two fractions with the most PSCHI4 as detected in western blots. B, Western blots of the same Rotofor fractions shown in A, along with purified recombinant PSCHI4 as a positive control for antibody recognition (lanes C). 
Our finding that PR genes are expressed in resistant seedlings after pathogen challenge supports the hypothesis that there is an inducible host response associated with resistance to pitch canker disease (Fig. 5A) (Davis et al. 1999). Such a hypothesis predicts the involvement of active defense mechanisms as opposed to structural or chemical barriers to infection. The pschi4 gene may be part of a regulon that is expressed in association with resistance. The timing of pschi4 induction should guide efforts to identify other genes in the regulon and ultimately improve our understanding of resistance responses in pine trees.

\section{Defense-signaling pathways in pines.}

SA and JA can act as pathogen signal-transducing molecules in plants. The timing and amplitude of their accumulation can depend upon whether the pathogen is biotrophic or necrotrophic (McDowell and Dangl 2000; Thomma et al. 2001). Transcript levels for all of the pine chitinase homologs tested were induced in response to either SA or JA, indicating a potential signaling role for these molecules. It is known that SA and other phenylpropanoid compounds are found in conifers and can accumulate in response to elicitors and pathogen challenge (Campbell and Ellis 1992; Franich et al. 1986). However, to our knowledge, there are no definitive data that place SA in a signaling pathway in the disease resistance response of conifers. Evidence that conifers are sensitive to JA was suggested by studies showing that spruce seedlings acquired resistance to Pythium-incited root rot disease after methyl jasmonate application (Kozlowski et al. 1999). However, JA was not detectable in conifer seedlings, even though quantitation was attempted using both pathogen-challenged and methyl jasmonate-treated
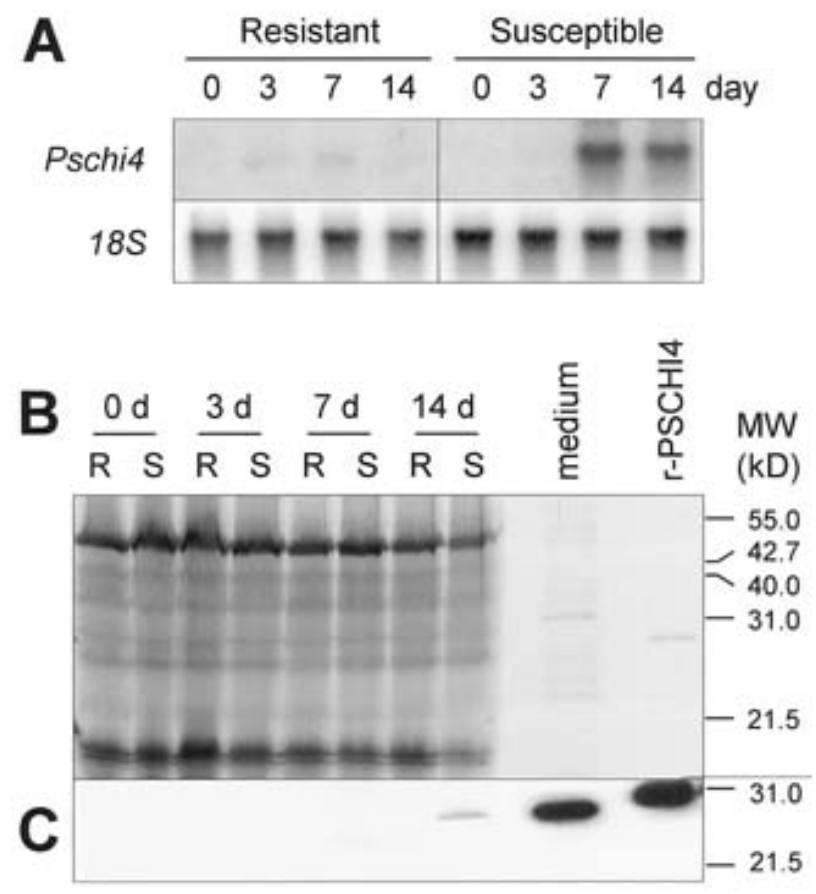

Fig. 5. pschi4 Is expressed at both mRNA and protein levels in response to pathogen challenge. A, Autoradiograph of a northern blot with total RNA (5 $\mu$ g per lane) from resistant (R) or susceptible (S) seedlings that were harvested at various times after challenge with Fusarium subglutinans f. sp. pini. The blot was hybridized to detect pschi4 and then stripped and reprobed with $18 \mathrm{~S}$ ribosomal RNA as a positive control for loading. B, Coomassie-stained gel, and $\mathbf{C}$, western blot after sodium dodecyl sulfate-polyacrylamide gel electrophoresis of protein samples extracted from the same experiment shown in A. Medium from chitosanelicited cell cultures and purified recombinant PSCHI4 were used as positive controls for antibody recognition. plants (Kozlowski et al. 1999). Richard and colleagues (2000) reported that jasmonate stimulated the accumulation of chalcone synthase transcripts in white spruce. Our results extend the above findings by establishing that multiple chitinase homologs are downstream of challenge by a necrotrophic pathogen and are potentially downstream of SA, JA, or both. These probes should aid in ongoing efforts to evaluate functional homology between PR gene regulatory pathways in angiosperms and gymnosperms and in identifying genes that are involved in acquired resistance in conifers.

In the angiosperm systems that are well-characterized, PR genes contain promoter motifs that act as the termini of pathogen-signaling pathways (Maleck et al. 2000; Menke et al. 1999). Knowing that the pathogen-associated signaling molecules SA and JA induce pine genes, we speculated that PR promoters from pine might contain promoter motifs identical to those in angiosperms. In a separate analysis, we searched seven pathogen-responsive conifer promoters (chitinase [pschil, GenBank accession no. U57409; and pschi4, GenBank accession no. U57410], stilbene synthase [pst-1, GenBank accession no. Y17594; pst-2, GenBank accession no. Y17595; pst-3, GenBank accession no. Y17596; and pst-5, GenBank accession no. Y17597], and peroxidase [spi2, GenBank accession no. AY028213]) for the defense-related, transcription factorbinding sites investigated by Maleck and colleagues (2000). In these pathogen-responsive promoters, and in the promoters of five conifer genes with nondefense roles, we found no more sites than would be expected by chance. One exception was pschil, which has four potential binding sites for the WRKY family of transcription factors (Eulgem et al. 2000) within a region $600 \mathrm{bp}$ upstream of the TATA sequence. However, pschil is judged to be a pseudogene because of a premature stop codon in its first exon (Wu et al. 1997) and is unlikely to encode a functional enzyme. The lack of any clearly defined promoter elements for known functional defense genes downstream of pathogen challenge supports the need to identify relevant motifs in conifer promoters. Such information will provide information on the downstream components of defense-signaling pathways in conifers and for comparisons between conifer and angiosperm promoters. In this paper, we report the identification of chitinase homologs whose promoters appear to anchor pathogen-, SA-, and JA-signaling pathways, thereby providing the probes needed to identify promoters with relevant motifs.

\section{Inducible responses to pathogen challenge.}

The symptoms of pitch canker disease include resin production, pigmentation, and in later stages of disease development, tissue desiccation. Consequently, many different genes and processes are likely to be induced in the pine host during pitch canker disease development. Whereas resin production is perhaps the most familiar and visible component of pine defense, expression of PR proteins is a potentially important response as well. PR genes of conifers include elicitor- and pathogeninduced genes involved in phenylpropanoid metabolism such as stilbene synthase (Muller et al. 1999), chalcone synthase (Richard et al. 2000), and phenylalanine ammonia-lyase (Butland et al. 1998). Hydrolytic enzymes such as chitinase also appear to be a prominent feature of the inducible defense profile of pine trees (Mason and Davis 1997; Popp et al. 1997), as they are in other conifers (Hodge et al. 1995; Kozlowski and Metraux 1998) and poplar trees (Clarke et al. 1998; Parsons et al. 1989). These findings have important implications for pine genomics projects, one goal of which is to create a catalog of genes for traits of ecological and economic importance. Disease traits are important in both respects, and as such, a catalog of pathogen defense-related genes would complement ongoing 
efforts to identify genes involved in wood formation in conifers (Allona et al. 1998).

\section{MATERIALS AND METHODS}

Recombinant PSCHI4 and antibody.

The pschi4 cDNA was cloned by RT-PCR from transgenic tobacco expressing a genomic subclone of pschi4 under the control of its own regulatory elements (Wu et al. 1997). Briefly, first-strand cDNA was a template for PCR with primers (5'-TCTGCACAACAAGAGTCGCATCC-3' and 5' GATTGGATGGGTTGGTAAGCGTAG-3') corresponding to nucleotides 864 to 887 and 1,760 to 1,782 , respectively (Wu et al. 1997), which was expected to amplify a product encoding mature PSCHI4 after removal of the N-terminal signal peptide. The pschi4 cDNA was made blunt with T4 DNA polymerase and subcloned into SmaI-linearized pUC19. The cloned cDNA was then subcloned into the BamHI-EcoRI sites of expression vector pET24d, and expression and purification of recombinant PSCHI4 was carried out in bacterial host BL21(DE3)pLysS cells according to the manufacturer's instructions (Novagen, Madison, WI, U.S.A.). PSCHI4 was purified in a model 422 electroeluter using methods recommended by the manufacturer (Bio-Rad, Hercules, CA, U.S.A.). Antiserum against PSCHI4 was prepared by Cocalico Biologicals (Reamstown, PA, U.S.A.).

\section{Plant materials.}

Pine and tobacco suspension cultures were established, maintained, and treated with chitosan by the procedures de- scribed by Popp and colleagues (1997). Slash pine (P. elliottii var. elliottii) seedlings were grown from seeds collected from individual open-pollinated trees, obtained from either the Cooperative Forest Genetics Research Program (T. White and G. Powell) or from the Forest Pathology collection (G. M. Blakeslee and W. Lante) at the University of Florida. Seeds were soaked in hydrogen peroxide $(20 \%)$ for $20 \mathrm{~min}$, rinsed three times in sterile distilled water, and sown on moist vermiculite. After germination, seedlings were transferred to $4 \times$ $22-\mathrm{cm}$ tubes containing sand, peat moss, and vermiculite (1:1:1), fertilized twice weekly following manufacturer's instructions (fertilizer 24:10:10; Peter's, Marysville, OH, U.S.A.), and then maintained in a chamber (Conviron, Winnipeg, ON, Canada; $30^{\circ} \mathrm{C}, 300 \mu \mathrm{mol} \mathrm{m} \mathrm{m}^{-2} \mathrm{~s}^{-1}$ photosynthetically active radiation [PAR]) under a 12-h-light/12-h-dark regimen to a height of approximately 15 to $20 \mathrm{~cm}$ prior to treatment.

\section{RNA and protein analyses.}

Total RNA was extracted from cells or plant tissues by previously described methods (Chang et al. 1993). Northern analysis was performed as reported previously (Wu et al. 1997). Western analysis of proteins from cell cultures was performed according to methods reported by Lawrence and colleagues (1997); proteins from seedlings were analyzed similarly, except that detection was performed using reagents in the ECLPlus kit (Amersham Pharmacia Biotech Inc., Piscataway, NJ, U.S.A.).

Defense-related transcripts were cloned as cDNAs by differential display of mRNA (Liang and Pardee 1992) with the

Table 1. Summary of pine chitinase homologs

\begin{tabular}{llllll}
\hline Class $^{\mathbf{a}}$ & Designation & Accession $^{\mathbf{b}}$ & Inducer & & Clone \\
\hline I & pechi1 & AF457092 & Wound & cDNA & This paper \\
I & pechi191 & AF457093 & Pathogen & cDNA & This paper \\
II & pschil & U57409 & NR & Genomic & Wu et al. 1997 \\
II & pschi4 & U57410 & NR & Genomic & Wu et al. 1997 \\
II & pec30 & U55011 & Chitosan & cDNA & Mason and Davis 1997 \\
IV & pechi73 & AF457094 & SA & cDNA & This paper \\
IV & pechi80 & AF457095 & SA & cDNA & This paper \\
IV & pechi155 & AF457096 & SA & cDNA & This paper \\
IV & pechi270 & AF457097 & Pathogen & cDNA & This paper \\
\hline
\end{tabular}

${ }^{a}$ Pine chitinase homologs assigned to class I, II, or IV based on domain structure (Collinge et al. 1993).

${ }^{\mathrm{b}}$ GenBank accession number.

${ }^{\mathrm{c}}$ Inducer refers to the treatment imposed on cell cultures (chitosan) or intact seedlings (wound, pathogen, or salicylic acid [SA]) that led to cDNA discovery by differential display. $\mathrm{NR}=$ not relevant (pschil and pschi4 were originally cloned by sequence homology, not transcript inducibility).

d All cDNA clones are partial (size range of approximately 200 to $370 \mathrm{bp}$ ).
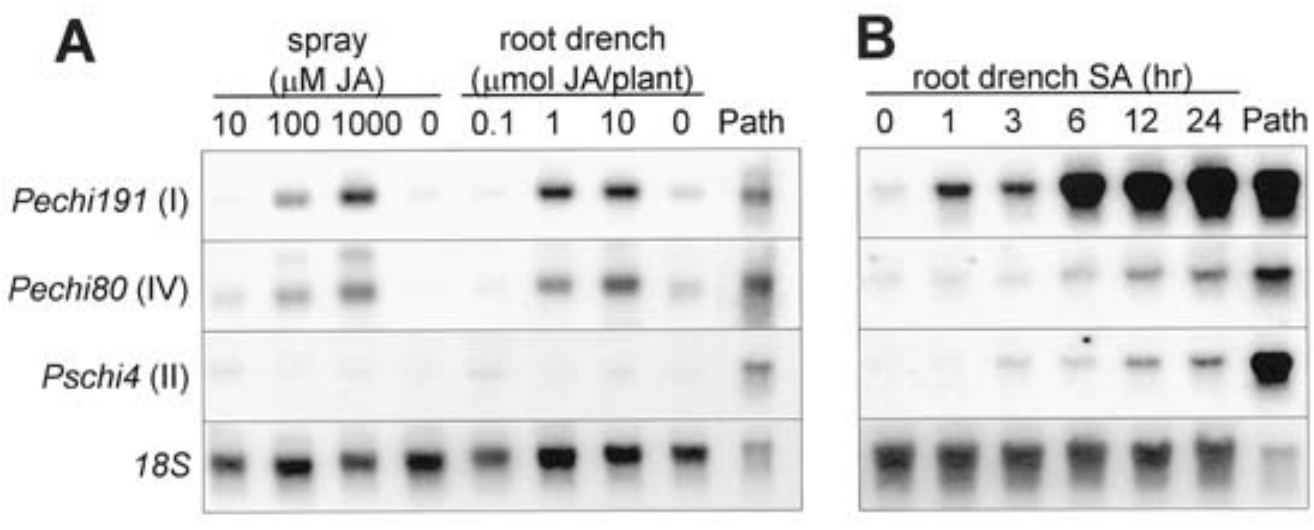

Fig. 6. Pine chitinase homologs are differentially regulated by jasmonic acid (JA), salicylic acid (SA), and challenge by Fusarium subglutinans f. sp. pini (Path). Northern blots contained total RNA (15 $\mu$ g per lane) from pine seedlings that were A, sprayed to foliar runoff, supplied with a soil drench of JA, or treated with carrier solution only (lanes 0); or B, supplied with a soil drench of SA and harvested as a time course. Lanes designated "Path" are positive controls for hybridization and contain $5 \mu \mathrm{g}$ of RNA from susceptible seedlings collected 14 days after challenge. Blots were hybridized with the probes designated on the left. 
RNAimage kit from GenHunter (Nashville, TN, U.S.A.). Briefly, differentially displayed products were selected from polyacrylamide gels (HR-1000; Beckman Coulter, Fullerton, CA, U.S.A.), reamplified, gel-purified with Qiaex resin (Qiagen, Valencia, CA, U.S.A.), ligated to the pGEM-T cloning vector (Promega, Madison, WI, U.S.A.), and transferred into competent E. coli cells (DH5 $\alpha$; BRL Life Sciences, Rockville, MD, U.S.A.). Plasmids were recovered with a miniprep kit (Qiagen) and sequenced by Arizona State University's DNA Sequencing Laboratory. Cloned inserts were amplified by PCR with T7 and SP6 primers, purified by Qiaex resin (Qiagen), and labeled with ${ }^{32} \mathrm{P}$ utilizing a random primer labeling kit (BRL Life Sciences) for northern analysis.

\section{Pathogen challenge and SA/JA treatments.}

F. subglutinans f. sp. pini isolate $\mathrm{S} 45$ (provided by the Forest Pathology laboratory collection, University of Florida) was initiated on potato dextrose agar (1\% agar) and transferred to carnation leaf agar (1\% agar) for continued growth. Macro- and microconidia were obtained from the leaf, placed into autoclaved distilled water, quantified with a hemocytometer, and diluted to 200 to 300 spores per $\mu$.

Seedlings from a resistant and a susceptible family were hedged and maintained to provide multiple shoots for pathogen inoculation. To inoculate seedlings, three to five primary needles were removed from individual shoots and the wound sites were cleaned with a cotton swab and inoculated with $1 \mu \mathrm{l}$ of the spore suspension. As a control, one shoot from each seedling received a $1-\mu \mathrm{l}$ droplet of autoclaved water at each wound site. Seedlings were maintained under humid conditions $(99 \%$ relative humidity) for $24 \mathrm{~h}$ and maintained in a growth chamber (Conviron; $30^{\circ} \mathrm{C}, 300 \mu \mathrm{mol} \mathrm{m} \mathrm{m}^{-2} \mathrm{~s}^{-1}$ PAR) under a 12-hlight/12-h-dark regimen. Shoots from resistant and susceptible seedlings were harvested at $0,3,7$, and 14 days postinoculation for RNA and protein extraction. Unless otherwise stated, pathogen-challenged samples used as positive controls in northern blots were from the 14-day-old samples from susceptible seedlings.

JA was sprayed to runoff or applied as a soil drench $(10 \mathrm{ml}$ per seedling) in a solution containing $0.01 \%$ Triton X-100 (vol/vol). Shoot tissues were harvested $12 \mathrm{~h}$ after treatment (five seedlings per treatment), and RNA was extracted for northern analysis. Sodium salicylate was applied as a soil drench $(10 \mathrm{ml}$ of a $10 \mathrm{mM}$ solution in water per seedling). Shoot tissues were harvested at each time point (15 seedlings each), and RNA was extracted for differential display and northern analysis. Chemicals were purchased from Sigma (St. Louis, MO, U.S.A.). Each experiment was repeated twice with similar results, and a representative autoradiograph is presented.

\section{Enzyme assays.}

To evaluate the enzymatic activity of PSCHI4 relative to other extracellular proteins, we fractionated the culture media from slash pine by preparative isoelectric focusing using a Rotofor apparatus and then removed ampholytes for protein quantitation and enzyme assays using mixed bed resin (Bio-Rad) as previously reported (Clarke et al. 1998). $\beta$ - $N$-Acetylglucosaminidase activity on each fraction was measured according to the methods of Hollis and colleagues (1997) by using 4-methylumbelliferyl- $\beta$-D- $N, N^{\prime}, N^{\prime \prime}$-triacetylchitotrioside (Sigma) as a substrate at a concentration of $250 \mu \mathrm{M}$. The fluorescent product was quantified in a TKO100 fixed wavelength fluorometer (Hoefer Scientific Instruments, San Francisco, CA, U.S.A.; excitation wavelength $365 \mathrm{~nm}$, emission wavelength $460 \mathrm{~nm}$ ). Lysozyme activity was assayed by using Micrococcus lysodeikticus cells (M3770; Sigma) suspended at 2\% (wt/vol) in 50 $\mathrm{mM}$ phosphate buffer $(\mathrm{pH}$ 6.0) as a substrate. Reactions were stopped by adding nine volumes of $0.5 \mathrm{M}$ glycine ( $\mathrm{pH} 12.0)$, and product was quantified in a SmartSpec3000 (Bio-Rad) at $450 \mathrm{~nm}$. Ten microliters of each fraction was incubated in duplicate reactions with a substrate for 0.25 and $1.25 \mathrm{~h}$ (chitinase) or for $5 \mathrm{~min}$ and $24 \mathrm{~h}$ (lysozyme). Each experiment was repeated at least once with similar results. The presence of PSCHI4 was assessed by western blotting with a dye-conjugated secondary antibody and the colorimetric procedures of Lawrence and colleagues (1997).

\section{ACKNOWLEDGMENTS}

This is journal article number R-08499 of the Florida Agricultural Experiment Station (FAES), which, along with the Defense Genes In Forest Trees cooperative (International Paper, Rayonier, Westvaco, Weyerhaeuser, and the USDA Forest Service-Southern Research Station and North Central Research Station), provided funding for this work. N-terminal sequencing was performed by the Protein Chemistry Core (Interdisciplinary Centers for Biotechnology Research, University of Florida). We thank T. E. Korhnak for carrying out differential display with such exceptional skill, C. Dervinis and K. Smith for technical assistance, and A. Morse for helpful suggestions on the manuscript. G. Blakeslee and M. Tignor helped develop the pitch canker disease screening procedure.

\section{LITERATURE CITED}

Allona, I., Quinn, M., Shoop, E., Swope, K., St. Cyr, S., Carlis, J., Riedl, J., Retzel, E., Campbell, M. M., Sederoff, R., and Whetten, R. W. 1998. Analysis of xylem formation in pine by cDNA sequencing. Proc. Natl. Acad. Sci. U.S.A. 95:9693-9698.

Benhamou, N., Joosten, M. H. A. J., and de Wit, P. J. G. M. 1990. Subcellular localization of chitinase and of its potential substrate in tomato root tissues infected by Fusarium oxysporum f. sp. radicis-lycopersici. Plant Physiol. 92:1108-1120.

Bishop, J. G., Dean, A. M., and Mitchell-Olds, T. 2000. Rapid evolution in plant chitinases: Molecular targets of selection in plant-pathogen coevolution. Proc. Natl. Acad. Sci. U.S.A. 97:5322-5327.

Blakeslee, G. M., and Rockwood, D. L. 1978. Variation in resistance of slash pine to pitch canker caused by Fusarium moniliforme var. subglutinans. (Abstr.) Phytopathol. News 12:207-208.

Broglie, K., Chet, I., Holliday, M., Cressman, R., Biddle, P., Knowlton, S., Mauvais, C. J., and Broglie, R. 1991. Transgenic plants with enhanced resistance to the fungal pathogen Rhizoctonia solani. Science 254:1194-1197.

Butland, S. L., Chow, M. L., and Ellis, B. E. 1998. A diverse family of phenylalanine ammonia-lyase genes expressed in pine trees and cell cultures. Plant Mol. Biol. 37:15-24.

Campbell, M. M., and Ellis, B. E. 1992. Fungal elicitor-mediated responses in pine cell-cultures. I. Induction of phenylpropanoid metabolism. Planta 186:409-417.

Chang, S., Puryear, J., and Cairney, J. 1993. A simple and effective method for isolating RNA from pine trees. Plant Mol. Biol. Rep. 11: 113-116.

Clarke, H. R. G., Lawrence, S. D., Flaskerud, J., Korhnak, T. E., Gordon, M. P., and Davis, J. M. 1998. Chitinase accumulates systemically in wounded poplar trees. Physiol. Plant. 103:154-161.

Collinge, D. B., Kragh, K. M., Mikkelsen, J. D., Nielsen, K. K., Rassmussen, U., and Vad, K. 1993. Plant chitinases. Plant J. 3:31-40.

Davis, J., Blakeslee, G., Luce, S., LaRussa, L., Tignor, M., and Michler, C. 1999. An approach to identify slash pine genes associated with tolerance to pitch canker disease. Pages 78-79 in: Current and Potential Impacts of Pitch Canker in Radiata Pine. Proc. IMPACT Monterey Workshop. M. E. Devey, A. C. Matheson, and T. R. Gordon, eds. CSIRO Australia, East Melbourne, Australia.

Dixon, R. A., and Harrison, M. J. 1990. Activation, structure and organization of genes involved in microbial defense in plants. Adv. Genet. 28:165-234.

Dixon, R. A., and Lamb, C. J. 1990. Molecular communications in interactions between plants and microbial pathogens. Annu. Rev. Plant Physiol. Plant Mol. Biol. 41:339-367.

Dong, J. Z., and Dunstan, D. I. 1997. Endochitinase and $\beta$-1,3-glucanase genes are developmentally regulated during somatic embryogenesis in Picea glauca. Planta 201:189-194.

Dwinell, L. D., and Phelps, W. R. 1977. Pitch canker of slash pine in Florida. J. For. 75:488-489.

Dwinell, L. D., Ryan, P. L., and Kuhlman, E. G. 1977. Pitch canker (Gibberella fujikuroi) of loblolly pine in seed orchards. Pages 130-137 in: 
Proc. South. Tree Improvement Conf., 14th. R. E. Goddard and A. E. Squillace, eds. Southern Forest Tree Improvement Committee.

Enyedi, A. J., Yalpani, N., Silverman, P., and Raskin, I. 1992. Signal molecules in systemic plant resistance to pathogens and pests. Cell 70: 879-886.

Eulgem, T., Rushton, P. J., Robatzek, S., and Somssich, I. E. 2000. The WRKY superfamily of plant transcription factors. Trends Plant Sci. 5:199-206.

Franich, R. A., Carson, M. J., and Carson, S. D. 1986. Synthesis and accumulation of benzoic acid in Pinus radiata needles in response to tissue-injury by dothistromin, and correlation with resistance of Pinus radiata families to Dothistroma pini. Physiol. Mol. Plant Pathol. 28: 267-286.

Graham, L. S., and Sticklen, M. B. 1994. Plant chitinases. Can. J. Bot. 72:1057-1083.

Grison, R., Grezes-Besset, B., Schneider, M., Lucante, N., Olsen, L., Leguay, J. J., and Toppan, A. 1996. Field tolerance to fungal pathogens of Brassica napus constitutively expressing a chimeric chitinase gene. Nat. Biotechnol. 14:643-646.

Hodge, G. R., and Dvorak, W. S. 2000. Differential responses of Central American and Mexican pine species and Pinus radiata to infection by the pitch canker fungus. New For. 19:241-258

Hodge, A., Alexander, I. J., and Gooday, G. W. 1995. Chitinolytic activities of Eucalyptus pilularis and Pinus sylvestris root systems challenged with mycorrhizal and pathogenic fungi. New Phytol. 131:255261

Hollis, T., Honda, Y., Fukamizo, T., Marcotte, E., Day, P. J., and Robertus, J. D. 1997. Kinetic analysis of barley chitinase. Arch. Biochem. Biophys. 344:335-342.

Jach, G., Gornhardt, B., Mundy, J., Logemann, J., Pinsdorf, E., Leah, R., Schell, J., and Maas, C. 1995. Enhanced quantitative resistance against fungal disease by combinatorial expression of different barley antifungal proteins in transgenic tobacco. Plant J. 8:87-109.

Kozlowski, G., and Metraux, J. P. 1998. Infection of Norway spruce (Picea abies (L) Karst) seedlings with Pythium irregulare Buism and Pythium ultimum Trow: Histological and biochemical responses. Eur. J. Plant Pathol. 104:225-234.

Kozlowski, G., Buchala, A., and Metraux, J. P. 1999. Methyl jasmonate protects Norway spruce (Picea abies (L.) Karst.) seedlings against $P$ ythium ultimum Trow. Physiol. Mol. Plant Pathol. 55:53-58.

Lawrence, S. D., Greenwood, J. S., Korhnak, T. E., and Davis, J. M. 1997. A vegetative storage protein homolog is expressed in the growing shoot apex of hybrid poplar. Planta 203:237-244.

Liang, P., and Pardee, A B. 1992. Differential display of eukaryotic messenger RNA by means of the polymerase chain reaction. Science 257 967-971.

Maleck, K., Levine, A., Eulgem, T., Morgan, A., Schmid, J., Lawton, K. A., Dangl, J. L., and Dietrich, R. A. 2000. The transcriptome of Arabidopsis thaliana during systemic acquired resistance. Nat. Genet. 26: 403-410.

Mason, M. E., and Davis, J. M. 1997. Defense response in slash pine: Chitosan treatment alters the abundance of specific mRNAs. Mol. Plant-Microbe Interact. 10:135-137.

Mauch, F., and Staehelin, A. 1989. Functional implications of the subcellular location of ethylene-induced chitinase and $\beta$-1,3-glucanase in bean leaves. Plant Cell 1:447-457.

Mauch, F., Mauch-Mani, B., and Boller, T. 1988. Antifungal hydrolases in pea tissue: II. Inhibition of fungal growth by combinations of chitinase and $\beta$-1,3-glucanase. Plant Physiol. 88:936-942.

McDowell, J. M., and Dangl, J. L. 2000. Signal transduction in the plant immune response. Trends Biochem. Sci. 25:79-82.

McKeever, D. B., and Howard, J. L. 1996. Value of timber and agricultural products in the United States, 1991. For. Prod. J. 46:45-50.

Menke, F. L. H., Champion, A., Kijne, J. W., and Memelink, J. 1999. A novel jasmonate- and elicitor-responsive element in the periwinkle secondary metabolite biosynthetic gene Str interacts with a jasmonateand elicitor-inducible AP2-domain transcription factor, ORCA2. EMBO (Eur. Mol. Biol. Organ.) J. 18:4455-4463.

Muller, R. P., Schwekendick, A., Brehm, I., Reif, H. J., and Kindl, H. 1999. Characterization of a pine multigene family containing elicitorresponsive stilbene synthase genes. Plant Mol. Biol. 39:221-229.

Neuhaus, J. M., and Rogers, J. C. 1998. Sorting of proteins to vacuoles in plant cells. Plant Mol. Biol. 38:127-144.

Parsons, T. J., Bradshaw, H. D., Jr., and Gordon, M. P. 1989. Systemic accumulation of specific messenger-RNAs in response to wounding in poplar trees. Proc. Natl. Acad. Sci. U.S.A. 86:7895-7899.

Phillips, M. A., and Croteau, R. B. 1999. Resin-based defenses in conifers. Trends Plant Sci. 4:184-190.

Popp, M. P., Lesney, M. S., and Davis, J. M. 1997. Defense responses elicited in pine cell suspension cultures. Plant Cell Tissue Organ Cult. 47:199-206.

Richard, S., Lapointe, G., Rutledge, R. G., and Seguin, A. 2000. Induction of chalcone synthase expression in white spruce by wounding and jasmonate. Plant Cell Physiol. 41:982-987.

Richardson, D. M., and Rundel, P. W. 1998. Ecology and biogeography of Pinus: An introduction. Pages 3-46 in: Ecology and Biogeography of Pinus. D. M. Richardson, ed. Cambridge University Press, Cambridge, U.K.

Rockwood, D. L., Blakeslee, G. M., Lowerts, G. A., Underhill, E. M., and Oak, S. W. 1988. Genetic strategies for reducing pitch canker incidence in slash pine. South. J. Appl. For. 12:28-32

Salzer, P., Hebe, G., and Hager, A. 1997a. Cleavage of chitinous elicitors from the ectomycorrhizal fungus Hebeloma crustuliniforme by host chitinases prevents induction of $\mathrm{K}+$ and $\mathrm{Cl}-$ release, extracellular alkalinization and $\mathrm{H}_{2} \mathrm{O}_{2}$ synthesis of Picea abies cells. Planta 203:470-479.

Salzer, P., Hubner, B., Sirrenberg, A., and Hager, A. 1997b. Differential effect of purified spruce chitinases and $\beta$-1,3-glucanases on the activity of elicitors from ectomycorrhizal fungi. Plant Physiol. 114:957968.

Schenk, P. M. Kazan, K, Wilson, I, Anderson, J. P., Richmond, T. Somerville, S. C., and Manners, J. M. 2000. Coordinated plant defense responses in Arabidopsis revealed by microarray analysis. Proc. Natl. Acad. Sci. U.S.A. 97:11655-11660.

Thomma, B. P. H. J., Penninckx, I. A. M. A., Broekaert, W. F., and Cammue, B. P. A. 2001. The complexity of disease signaling in Arabidopsis. Curr. Opin. Immunol. 13:63-68.

Wu, H., Echt, C. S., Popp, M. P., and Davis, J. M. 1997. Molecular cloning, structure and expression of an elicitor-inducible chitinase gene from pine trees. Plant Mol. Biol. 33:979-987.

Wu, H., Michler, C. H., LaRussa, L., and Davis, J. M. 1999. The pine pschi4 promoter directs wound-induced transcription. Plant Sci. 142: 199-207.

Yang, Y., Jyoti, S., and Klessig, D. F. 1997. Signal perception and transduction in plant defense responses. Genes Dev. 11:1621-1639. 